\title{
Ornamental Plants of Home Garden along the Coridor of Kopendukuh Village, Banyuwangi, East Java-Indonesia as a Basis for Ecotourism Planning
}

\author{
Maic A. L. Sihombing*, Ade M.C. Rohie, Nawafila Februyani, Rosalina E. Swandayani
}

Master Program of Biology, Faculty of Mathematic and Natural Sciences, University of Brawijaya, Malang, Indonesia

\begin{abstract}
Home garden is a habitat for many plants species which are important in planning and management of tourism in rural area. Ornamental plants have crucial function to increase the appearance of homes and buildings through landscaping. The purpose of this study is to analyze ornamental plants species which grow in the home garden along the corridor of Kopendukuh Village as one of the potential attractions of tourism development. The observation of ornamental plants diversity was carried out at home gardens along the rural coridor of Kopendukuh Village. Totally, there are about 10 home gardens were assessed. In each home gardens, plans species were recorded and identified systematically. Qualitative analysis was performed using analysis of sociability, vitality, and periodicity. Result of the survey confirm that home garden is home of about 40 ornamental plants species. These species came from 24 family. About $59 \%$ of the ornamental species was classified as individual plant species live in small groups, $28 \%$ of ornamental plant was classified as shrubs. About $65 \%$ of are ornamental plant without flowers and seeds. The diversity of plants in home garden needs special attention, especially in order to increase settlement visual quality.
\end{abstract}

Keywords: Kopendukuh, ornamental plant, sociability, vitality, periodicity.

\section{INTRODUCTION}

Rural tourism destination is a rural area that has some special characters and attractions to become a tourist destination [1]. The interaction of local people and plants is one of the interesting tourism object $[2,3]$. Local plants are usually grown by the people in the home garden as an additional economic income. Local-home garden plants with high diversity can provide conservation value along the travel corridors of the village [4]. Home garden is a habitat for many plants species that act as a critical resource in planning and management of tourism [1]. Home garden is a piece of land that is located around the residence and clearly demarcated, planted with one or a variety of plants and still have a relationship with home ownership. When properly maintained, the land can increase scenic beauty of environment. Home garden can be planted with various types of plants that produce and required daily [5].

The important role of home garden in rural areas in developing countries has been widely reported [1]. Home garden also contribute to biodiversity conservation and environment. Home garden can be empowered to various commodities (crops and livestock) and can be

\footnotetext{
${ }^{*}$ Correspondence address:

Maic A.L. Sihombing

Email : maicaudolinsihombing@gmail.com

Address : Master Program of Biology, University of Brawijaya, Jl. Veteran. Malang 65145.
}

integrated from fruit trees, vegetables, herbs, plantation crops, and animal husbandry [6].

Ornamental plant is a plant that can be shaped herb, vines, bushes, shrubs, or trees, planted as a component of the home garden which has unique form, distinctive and serves as a decoration to beautify and embellish both indoor and outdoor [7]. Ornamental plant has function to increase the appearance of homes and buildings through landscaping, open land abolish useless and increase the number of green open areas. In landscape architecture, the shape and placement of plants are important considerations.

Kopendukuh Village in Banyuwangi Regency has been developed as a rural tourism destination. Based on some resources of the village, the ornamental plant in home garden is one of crucial component that can be used as a tourist attraction. Environment quality in tourism area able to provide satisfaction and it can be used as a vehicle for education to tourists. Among the benefits of the home garden, the contribution of home garden in rural tourism destination development is rarely discussed [1].

Understanding the motives of planting some ornamental species by the local people is very important and allows planners to improve the vegetation quality of home garden which is becomes extremely important in areas adjacent to the attraction. Improving home gardens quality can be a crucial strategy to improve tourism destination quality. The purpose of this 
study is to analyze ornamental plants species which grow in the home garden along the corridor of Kopendukuh Village as one of the potential attractions of tourism development and the data is crucial for the future tourism destination planning.

\section{MATERIALS AND METHODS Study Area}

The study area is located at the home garden along the rural coridor of Kopendukuh Village. Kopendukuh Village is one of the nine villages in Giri District. It is located in the northern part of Banyuwangi Regency, East Java Province, Indonesia. Giri District is one of 24 districts in Banyuwangi Regency with total area covers 21,31 $\mathrm{km}^{2}$.

Kopendukuh is a traditional village which located at the left slope of $\mathrm{Mt}$. Ijen with coordinates position at $08^{\circ} 09^{\prime} 47.7^{\prime \prime}$ South Latitude to $114^{\circ} 17^{\prime} 36,6^{\prime \prime}$ East Longitude and $08^{\circ}$ $09^{\prime} 45.7^{\prime \prime} \mathrm{SL}$ to $114^{\circ} 17^{\prime} 38.7^{\prime \prime}$ East Longitude. The village is home for 500 householders.

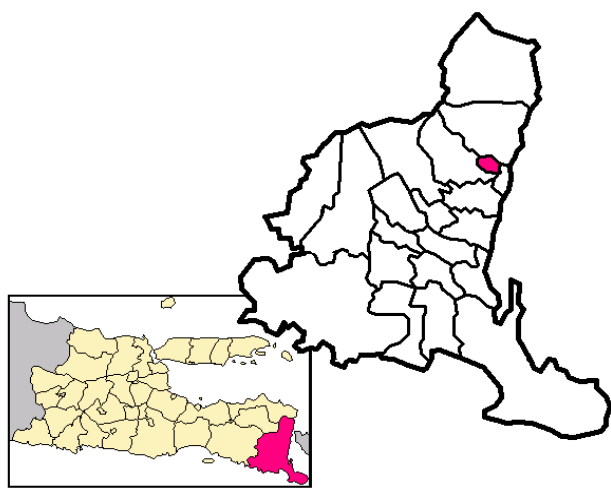

Figure 1. Map of Kopendukuh Village, Giri District, Banyuwangi, East Java-Indonesia [13]

\section{Sampling Procedure}

The study was conducted in November 2014 to determine the diversity of ornamental plants species in home garden along the rural corridor of Kopendukuh Village. Preliminary study conducted to obtain information about the condition of the research sites. The next step is filed observations at every house that has a yard. One house with its garden was considered as one plot observation. The plot that has been observed is home with the yard that have at least 3 types of ornamental plants. Plot is mapped using GPS (Global Positioning System). There are about 10 plots in the home garden were involved in this study. The plant species which are grown in home garden was recorded and identified using standard plant identification book [8]. At the same time also conducted interviews with homeowners. Some of the questions related about the use of ornamental plants and the plant maintenance process.

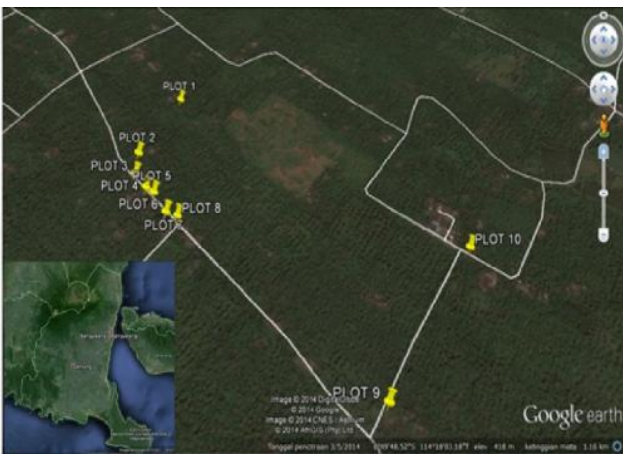

Figure 2. Study area at Kopen Dukuh Village. Pin indicates sampling locations[14].

\section{Analysis Data}

Ornamental plant description was conducted using qualitative analysis. Qualitative analysis was performed to describes plant's sociability, vitality, and periodicity [9]. Sociability analysis was conducted in order to know the size of a certain population plant species on the site. Vitality analysis was conducted in order to determine the growth conditions and the presence of buds on a particular plant species. Periodicity analysis was conducted in order to determine the existence of a planting time to bedating through the presence of fruit and seeds as generative organs of plants.

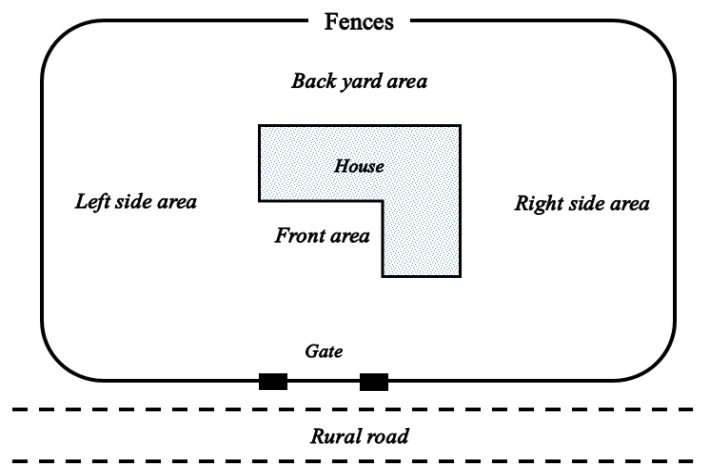

Figure. 3. Spatial Arrangment of Home Gardens in Kopen Dukuh [1].

\section{RESULTS AND DISCUSSION}

Species Diversity and Distribution of Ornamental Plants

Distribution of ornamental plants along the rural coridor of Kopendukuh Village was centered on the 10 plots that can be seen in Fig. 2. There are about 40 ornamental plants species were 
found. These species came from 24 families (Table 1.).

Home gardens in Kopendukuh commonly consist of three zones, front area, left side and right side area that are used for planting ornamental and fruit plants. The ornamental plants are planted to improve scenic beauty of the home. Back yard is the area where many plants grow in multi-cropping system. Tall and giant trees are often found in the back yard. Some plants even have huge canopy [1].

The ornamental plants were abundant in front area. The Euphorbiaceae, such as Jatropha curcas, Jatropha gossypifolia, Acalypha siamensis, and Euphorbia mili, were planted in front area, and were used to improve visual quality of the house. Other common species are the members of Apocynaceae, Plumeria sp. and Rosa hybrida. Ornamental plants are important to increase the scenic beauty of environment.

Table 1. Ornamental Plants List in Kopendukuh

\begin{tabular}{|c|c|c|}
\hline Family & Species & Local Name \\
\hline \multirow{7}{*}{ Euphorbiaceae } & Acalypha siamensis & $\begin{array}{l}\text { Bunga pagar } \\
\text { (teh-tehan) }\end{array}$ \\
\hline & Cydista aequinoctialis & Bunga bawang \\
\hline & Codiaeum sp. & Puring \\
\hline & Euphorbia mili & Euphorbia \\
\hline & Jatropha curcas & Jarak pagar \\
\hline & Jatropha gossypifolia & Jarak merah \\
\hline & Ixora javanica & Soka \\
\hline \multirow{4}{*}{ Araceae } & Anthurium Plowmanii & $\begin{array}{l}\text { Gelombang } \\
\text { cinta }\end{array}$ \\
\hline & Caladium bicolor & Keladi merah \\
\hline & Dieffenbachia amoena & Beras kutah \\
\hline & Spathiphyllum sp. & Lili kampung \\
\hline \multirow{3}{*}{ Areaceae } & Cocos nucifera & Kelapa gading \\
\hline & Hyphorbe lagenicaulis & Palem botol \\
\hline & Roystonea & Palem raja \\
\hline \multirow{2}{*}{ Asteraceae } & Cosmos caudatus & Kenikir \\
\hline & Plucehea indica & Beluntas \\
\hline \multirow{2}{*}{ Cycadaceae } & Cycas rumphii & Pakis haji \\
\hline & Zamia variegata & Zamia kulkas \\
\hline \multirow{2}{*}{ Liliaceae } & Amarvilis sp. & Bunga bakung \\
\hline & Dianella tasmanica & Lili-lilian \\
\hline Acanthaceae & Pachystachys lutea & Bunga lilin \\
\hline Agavaceae & Cordyline fruticosa & Andong \\
\hline Agavaceae & Sansevieria trifasciata & Lidah mertua \\
\hline Amaranthaceae & Alternanthera amoena & Bayam merah \\
\hline Apocynaceae & Plumeria sp. & $\begin{array}{l}\text { Kamboja bunga } \\
\text { putih }\end{array}$ \\
\hline Araliaceae & Talinum crassifolium & Ginseng jawa \\
\hline Arecaceae & Aglonema sp. & Aglonema \\
\hline Bromeliaceae & Bromelia sp. & Nanas-nanasan \\
\hline Cactaceae & Opuntia ellisiana & Kaktus \\
\hline Crassulaceae & Kalanchoe sp. & Cocor bebek \\
\hline Dracaenaceae & Dracaena angustifolia & Suji \\
\hline Fabaceae & Arachis pintoi & Kacang hias \\
\hline Malvaceae & Hibiscus rosasinensis & Bunga sepatu \\
\hline Nyctaginaceae & Bougainvillea sp. & Bougenville \\
\hline
\end{tabular}

\begin{tabular}{lll}
\hline Family & Species & Local Name \\
\hline Oleaceae & Jasminum sambac & Melati \\
\hline Orchidaceae & Spathoglottis plicata & Anggrek tanah \\
\hline Piperaceae & Piper bettle & Sirih \\
\hline Poaceae & Bambusa vulgaris & Bambu kuning \\
\hline Polypodiaceae & $\begin{array}{l}\text { Platycerium } \\
\text { bifurcatum }\end{array}$ & Tanduk rusa \\
\hline Rosaceae & Rosa Hybrida & Mawar \\
\hline
\end{tabular}

Inventory result showed that there are 10 ornamental plants species found abundantly along the rural corridor of Kopendukuh Village (Figure 4; Table 2). Cordyline fruticosa L., Codiaeum sp. and Acalypha siamensis were found almost in all of the plot observation. Local people in Kopendukuh used Cordyline fruticosa, Codiaeum sp. and Acalypha siamensis as a plant barrier of their home.

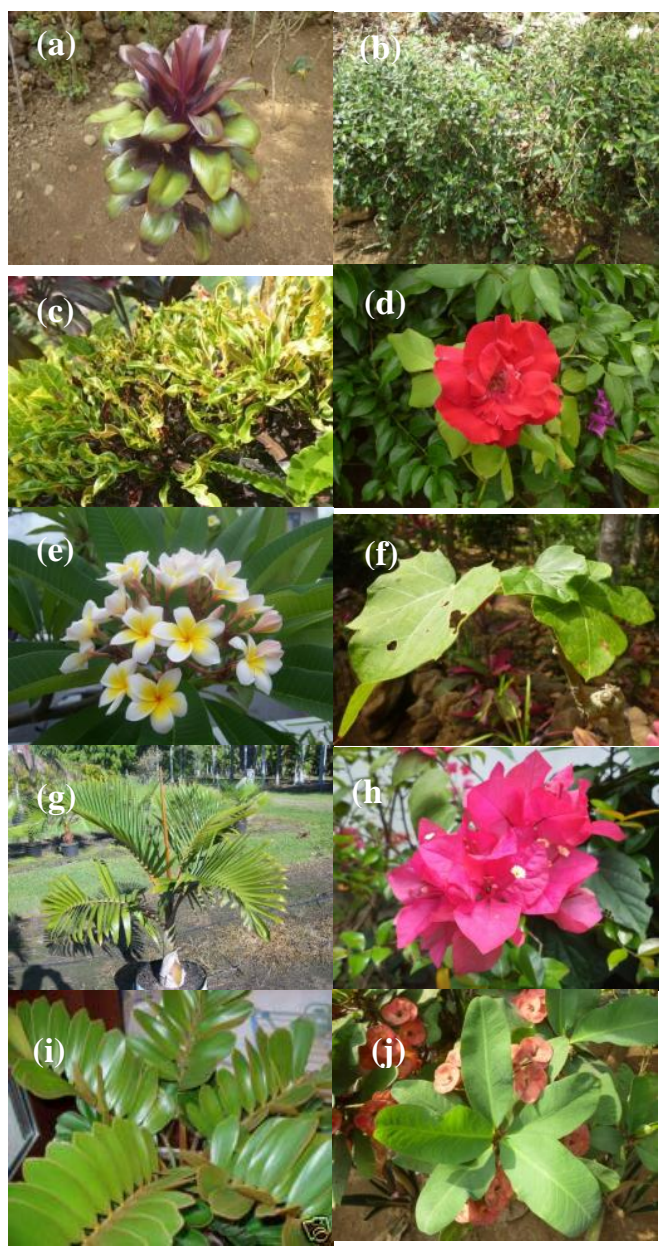

Figure. 4. Ornamental plants in Kopendukuh village (a) Cordyline fruticosa L; (b) Acalypha siamensis; (c) Codiaeum sp.; (d) Rosa hybrida; (e) Plumeria sp.; (f) Jatropha curcas L.; (g) Hyphorbe lagenicaulis; (h) Bougainvillea sp.; (i) Zamia variegata; (j) Euphorbia mili. 
Table 2. List of ornamental plant species abundantly found along the rural corridor of Kopendukuh Village

\begin{tabular}{lllll}
\hline No. & Species & Family & Habitus & Freq \\
\hline $\mathbf{1}$ & Cordyline fruticosa & Agavaceae & Shrub & 0.8 \\
\hline $\mathbf{2}$ & Acalypha siamensis & Euphorbiaceae & Shrub to small tree & 0.5 \\
\hline $\mathbf{3}$ & Codiaeum sp. & Euphorbiaceae & Shrub to small tree & 0.5 \\
\hline $\mathbf{4}$ & Rosa hybrida & Rosaceae & Shrub & 0.4 \\
\hline $\mathbf{5}$ & Plumeria sp. & Apocynaceae & Tree & 0.4 \\
\hline $\mathbf{6}$ & Jatropha curcas & Euphorbiaceae & Semak & 0.4 \\
\hline $\mathbf{7}$ & Hyphorbe lagenicaulis & Areaceae & Tree & 0.4 \\
\hline $\mathbf{8}$ & Bougainvillea sp. & Nyctaginaceae & Shrub & 0.4 \\
\hline $\mathbf{9}$ & Zamia variegata & Cycadaceae & Shrub & 0.3 \\
\hline $\mathbf{1 0}$ & Euphorbia mili & Euphorbiaceae & Shrub & 0.3 \\
\hline
\end{tabular}

Rosa hybrida, Plumeria sp., Jatropha curcas, Hyphorbe lagenicaulis Bougainvillea sp., Zamia variegata, Euphorbia mili were planted by local people to improve visual quality of the house.

Villagers in Kopendukuh generally utilize ornamental plants as a hedge plant. Plant is one of the constituent elements of the fence. Plants provide alternative materials as a yards fence of the house. In addition for functioning as a barrier plots or ownership, there are some functions and other benefits from the use of border plants. Border plant has a variety of functions such as increase beauty of a building, as a barrier against dust, pollution and radiation sunlight [10].

Cordyline fruticosa, Codiaeum sp. and Acalypha siamensis are used by local people as a border plants. These plants are suitable plant for use as fence. Types of border plants are generally annual, have long life cycle or have a long growing age and growth is relatively slow. It is intended that the use of plants can be longer (long life time) so that the plant does not need to be replaced and the pruning is not too frequent [10].

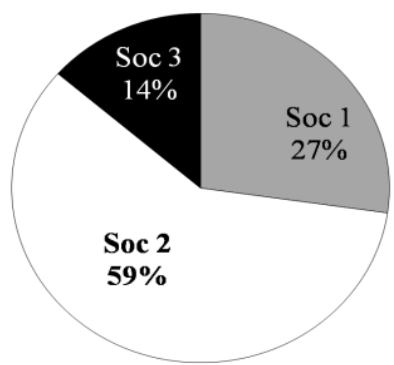

(a)

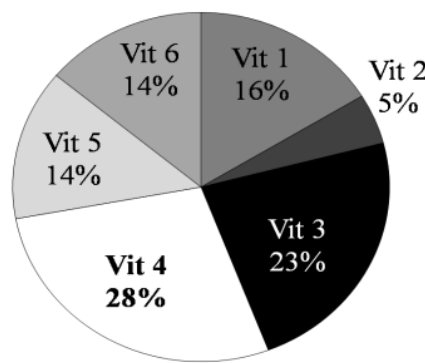

(b)

\section{Sociability of Ornamental Plant}

Sociability is an overview on the existence of a species in a population, in this case is the existence of ornamental plants that grows in Kopendukuh village. Ornamental plants in this area are known to be found live in condition solitary, small group and large group of population. High degrees of sociability can be seen if the plant has high seed productivity, ability to grow high and great adaptability [11].

Distribution of the ornamental plants in kopendukuh village was found diverse in each plot. Based on data (Fig. 5) there are some plants that live individual or solitarily (1) with percentage $14 \%$ there are $R$. hybrida, Plumeria sp., J. curcas, H. lagenicaulis, Bougainvillea sp. , $Z$. variegata and E. Milli. About 59\% percent of the ornamental plants are living in a small population $<50$ (Soc 2) were found in each plot, while $A$. siamensis and Codiaeum sp. are in large population $(>50)$ can be found only in several plot with percentage $27 \%$.

Figure 5. Qualitative analysis percentage of ornamental plants in Kopendukuh village. (a) Sociability; Soc 1 (Individual plant species live solitary), Soc 2 (Individual plant species live in small groups <50), Soc 3 (Individual plant species live in large group >50) (b) Vitality; Vit 1 (Found in the form of shrubs, growing well, and there are shoots or tillers), Vit 2 (Found in the form of shrubs, not growing well, and there are shoots or tillers), Vit 3 (Found in the form of shrubs, growing well, and no shoots or tillers), Vit 4 (Found in the form of shrubs, not growing well, and no shoots or tillers), Vit 5 (Found in the form of a bush, growing well, and there are shoots or tillers), Vit 6 (Found in the form of a bush, not growing well, and there are shoots or tillers) (c) Periodicity; Per 2 (Flowers only), Per 4 (No flowers and seeds were found). 
People in Kopendukuh village are deliberately cultivated these plant for the aesthetic value and used them as a border plant. For example an ornamental plant $A$. siamensis is found in large population because they were easy to be formed, with design pattern that we want. These ornamental plants also has a vary shape and color leaf so it's very popular as a home garden plants. Thus the ornamental plants can become neat and beautiful for a home garden with aesthetic value.

Based on data in Fig. 5, the percentage of sociability in Kopendukuh village was dominated with sociability 2 (59\%), an individual species living in small group $>50$. Sociability of a plant can be influenced by several things, including human impact or contribution and habitat conditions. The existence of ornamental plant communities in Kopendukuh village is known to have a diverse distribution pattern and live in small populations due to human influence.

\section{Vitality of Ornamental Plants}

Based on the analysis of general vitality can be seen that the populations were widely spread in the homegarden Kopendukuh Village is interest C. fruticosa L., A. siamensis and Codiaeum sp. The three types of this flower is easy to grow well in the yard citizens, has habitus shrubs, and have many shoots or tillers in the flower so that the population is in large quantities. According to the interview on the citizens, the plant were obtained from a funeral or found easily in the area of the village so that people feel the plant is easy to cultivate. In addition, many flowering plants are used as ornamental plants are Plumeria sp., R. hybrida, and E. milli. This group of flowering plant belong to trees and shrubs.

Based on the results of vitality diagram (Fig. 5) it can be seen that the highest value is vitality 4 (plants with traits that have habitus trees) as much as $28 \%$ is $R$. hybrida, Plumeria sp., $H$. lagenicaulis. The second highest is vitality 3 as much as $24 \%$ with categories the plant have habitus bush such as Cordyline fruticosa L. , Zamia variegata, and Euphorbia mili. The plants that was found in general is a plant that can live in tropics and upland areas. Types of the plants were analyzed using the values of vitality and declared that the whole plant have habitus bushes, shrubs, and trees. Some plants have shoots and seeds, but some are not having shoots and seeds. The results of the analysis can be used as an indicator of vitality is to see the future of plant populations and determine the influence of the environment with plant growth.

\section{Periodicity of Ornamental Plants}

Based on a research, there are 10 kinds of plants with the highest frequency of occurrence in each plot. The data is presented in a table that shows the periodicity of each population. The type of Cordyline fruticosa L., Acalypha siamensis, Jatropha curcas L., Hyphorbe lagenicaulis, and Zamia variegate is an ornamental plant species with a periodicity of 4 that is not found flowers and seeds with a percentage of $65 \%$. While Rosa Hybrida, Plumeria sp, Bougainvillea sp, Euphorbia milli with periodicity 2 and found the flowers with a percentage of periodicity $35 \%$ (Fig 5.).

Flowering phase in tropical plants started in the dry season but this research was conducted in November 2014 and was beginning the rainy season in East Java Province [12]. In addition, the pattern of flowering in tropical plant species are complex. Variations in climate can make plants more sensitive, for example effects on pollinators, seed pollination agents or predators. Therefore some ornamental plants not found flowering and seed plants.

\section{CONCLUSION}

Distribution of ornamental plants are mostly found along rural roads in Kopendukuh village is Euphorbiaceae with seven species. Method of this research was conducted using qualitative analysis. First analysis is sociability, showed that the highest value was individual species living in small groups $(<50)$. Second analysis was vitality with percentage of $28 \%$ (mostly herbaceous plants, can thrive but no buds). Third is periodicity analysis with the highest value is periodicity 4, which means that the plants are found doesn't have flowers and seeds.

\section{ACKNOWLEDGEMENTS}

We would like to send our gratitude to all the people living in Kopendukuh village Banyuwangi for giving us permission and kindly spent their time to give us a lot of information. We also feel grateful to Mr. Samuel for helping us throughout the observation process for most of home gardens area and to accompany us to see some tourist atractions.

\section{REFERENCES}

[1] Pamungkas, R. N., S. Indriyani and L. Hakim. 2013. The ethnobotany of homegardens along rural corridors as a basis for 
ecotourism planning: a case study of Rajegwesi village, Banyuwangi, Indonesia. Journal of Biodiversity and Environmental Sciences 3 (9), 6-69.

[2] Oktavianti, E., and L. Hakim. 2013. Ethnobotany Home Garden of Homestay in Tambak Sari Tourism Village, Purwodadi, Pasuruan, East Java. Journal of Indonesian Tourism and Development Studies 1 (1), 3945.

[3] Baud-Bovi M, Lowson F. 2002. Tourism and Recreation: Handbook of planning and design. Architectural press, Oxford.

[4] Hakim L., Nakagoshi N. 2007. Plant species Composition in Home gardens in the Tengger Highland (East Java Indonesia) and its Importance for Regional Ecotourism planning. Hikobia. 15, 23-36.

[5] Pendong, D. F., and Aprijani. 2004. Diversity of Plant Yard in Tomohon, North Sulawesi. Biosmart 6 (1).

[6] Widati, F., and Iteu M. Hidayat. 2012 Vegetable Soybean (Glycine max L. Merill) As Plant Yard. Horticultural Science 8.

[7] Acquaah, G. 2002. Horticulture-Principles and Practices, Second Edition. Prentice.

[8] Backer, C. A. Bakhuizen van den Brink, R. C. 1963. Flora of Java. Vol. 1. N.V. P. Noordhoff, Groningen, The Netherlands.

[9] Mubarok, F. 2012. Mapping the Distribution and Character of Edelweiss Populations Along The Hiking Trail Ranupani-Kalimati. Thesis. Department of Biolofy, University of Brawijaya.

[10] Werdiningsih, H. 2007. Study of Using Plants as an Alternative Fence Houses. Enclosure 6 (1).

[11] Barbour, M.G., J.H. Burk and W.D. Pitts. 1987. Terrestrial Plant Ecology. The Benjamin/Cummings Publishing Company, Inc. California.

[12] BMKG. 2014. Weather Forecast In Banyuwangi. East Java. http://www.bmkg. go.id/BMKG_Pusat/Informasi_Cuaca/. Accessed December $19^{\text {th }} 2014$.

[13] Wikimap. 2014. Map of Banyuwangi, East Java. http://wikimapia.org/\#lang=en\&lat=$8.200000 \&$ lon $=114.370000 \& z=13 \& m=b \&$ se arch=banyuwangi. November $10^{\text {th }} 2014$.

[14] Google Earth. 2003. Map of Banyuwangi, East Java. https://www.google.com/earth. November $14^{\text {th }} 2014$. 